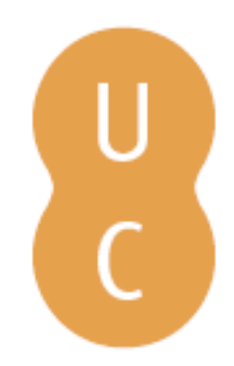

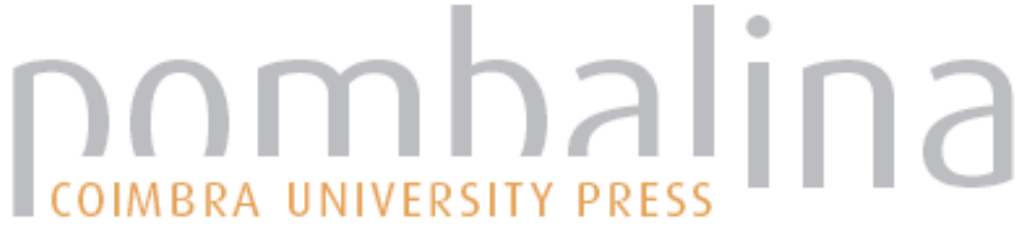

\section{Velhos e novos combates pela Universidade e pela história}

Autor(es): $\quad$ Torgal, Luís Reis

Publicado por: Imprensa da Universidade de Coimbra

URL

persistente: URI:http://hdl.handle.net/10316.2/31648

DOI: $\quad$ DOI:http://dx.doi.org/10.14195/978-989-26-0199-1_38

Accessed : $\quad$ 26-Apr-2023 13:07:51

A navegação consulta e descarregamento dos títulos inseridos nas Bibliotecas Digitais UC Digitalis, UC Pombalina e UC Impactum, pressupõem a aceitação plena e sem reservas dos Termos e Condições de Uso destas Bibliotecas Digitais, disponíveis em https://digitalis.uc.pt/pt-pt/termos.

Conforme exposto nos referidos Termos e Condições de Uso, o descarregamento de títulos de acesso restrito requer uma licença válida de autorização devendo o utilizador aceder ao(s) documento(s) a partir de um endereço de IP da instituição detentora da supramencionada licença.

Ao utilizador é apenas permitido o descarregamento para uso pessoal, pelo que o emprego do(s) título(s) descarregado(s) para outro fim, designadamente comercial, carece de autorização do respetivo autor ou editor da obra.

Na medida em que todas as obras da UC Digitalis se encontram protegidas pelo Código do Direito de Autor e Direitos Conexos e demais legislação aplicável, toda a cópia, parcial ou total, deste documento, nos casos em que é legalmente admitida, deverá conter ou fazer-se acompanhar por este aviso.

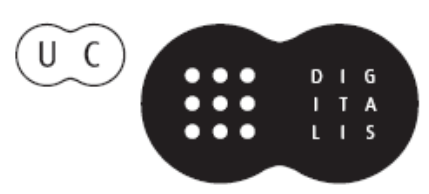


Maria Manuela Tavares Ribeiro

Coordenação

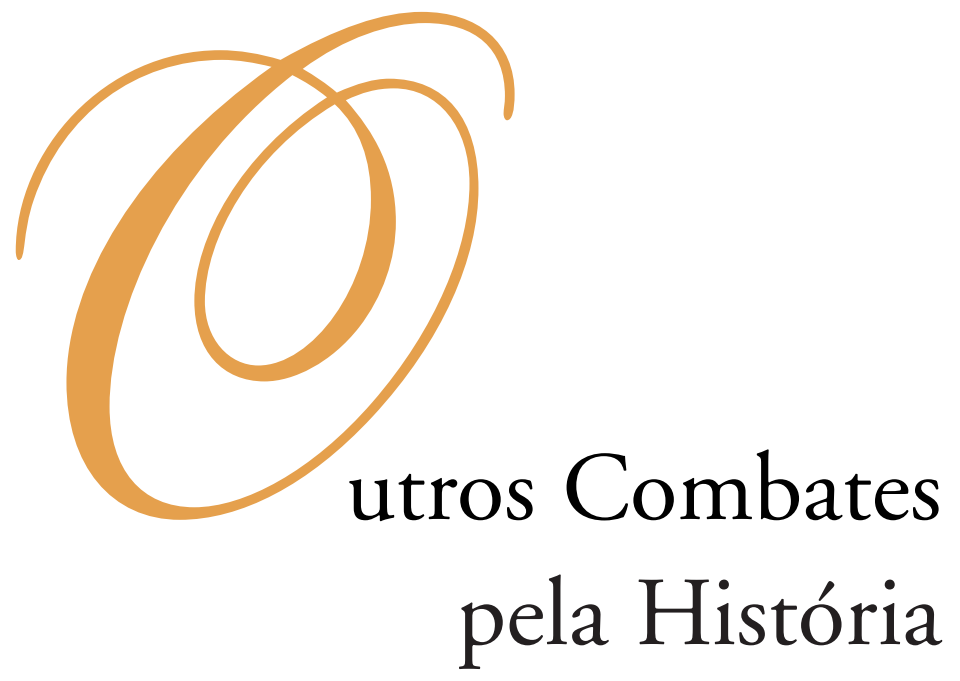




\section{COORDENAÇĀO EDITORIAL}

Imprensa da Universidade de Coimbra

Email: imprensauc@ci.uc.pt

URL: http://www.uc.pt/imprensa_uc

Vendas online: http://livrariadaimprensa.com

\section{CONCEPÇÃO GRÁFICA}

António Barros

\section{ORgANIZAÇĀO DOS TEXTOS}

Isabel Maria Luciano

Marlene Taveira

PRÉ-IMPRESSÃO

António Resende

Imprensa da Universidade de Coimbra

EXECUÇÃO GRÁFICA

SerSilito • Maia

ISBN

978-989-26-0041-3

DEPósito LEGAL

OBRA PUBLICADA COM O APOIO DE:

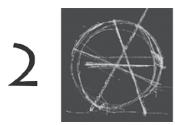

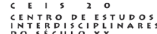

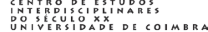

FCT Fundação para a Ciência e a Tecnologia

MINISTÉRIO DA CIÊNCIA, TECNOLOGIA E ENSINO SUPERIOR Portugal

Programa Operacional Ciência, Tecnologia, INOVAÇĀo DO QUADRo COMUNITÁRIO DE APOIO III

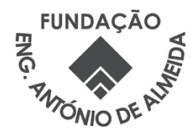

C JULHO 2010, IMPRENSA DA UNIVERSIDADE DE COIMBRA 
Maria Manuela Tavares Ribeiro

Coordenação

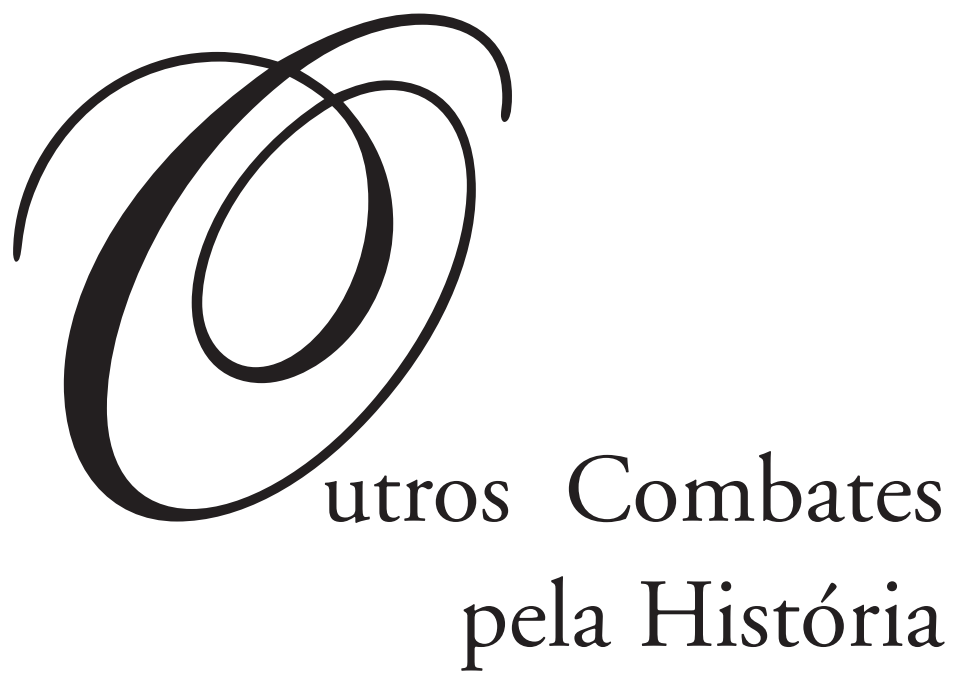

- colmbra 2010 
ENCERRAMENTO 


\section{Luís Reis Torgal}

\section{Velhos E NOVOS COMBATES PElA UNIVERSIDAde E PELA HistóRIA}

\section{A história oficial e a história "privada» do CEIS20}

O Centro de Estudos Interdisciplinares do Século XX da Universidade de Coimbra perfaz por esta altura dez anos. Este foi verdadeiramente o motivo da nossa celebração, com a realização de um interessante colóquio - mais um... - sobre um tema da maior actualidade, a que se chamou, por clara inspiração de uma obra de Lucien Fèbvre, «Novos Combates pela História». Por isso, como membro do CEIS20 e seu mais antigo investigador, coube-me a honra de encerrar este encontro. Orgulho-me desta minha representação e do decénio que já passou, aspirando a estar presente na próxima celebração, que há-de ocorrer em 2018.

Não devemos agradecer a nós próprios nem aos amigos, mas não quero deixar de saudar a minha colega Prof. ${ }^{a}$ Maria Manuela Tavares Ribeiro, actual coordenadora científica deste Centro, e o meu colega Professor João Rui Pita, vice-coordenador, que comigo colaborou directamente na formação do Centro em anos anteriores a 1998. Eles ergueram este colóquio, apoiados por outros colegas (que peço desculpa de não identificar) e pelos membros não investigadores do CEIS20 (propositadamente não lhe quis chamar «funcionários», num tempo caracterizado pela existência de "funcionários», "gestores» e "burocratas», que matam, tantas vezes, a nossa liberdade e o nosso gosto de pensar e de trabalhar). Eles pertencem ao centro como cada um de nós (os que pesquisam em História), vivendo os seus problemas.

O CEIS20 não é, porém, uma invenção minha. Ele mergulha num tempo já (para mim) impreciso em que orientei uma equipa de investigadores que não pertenciam à Universidade de Coimbra. A ideia surgiu da Doutora Heloisa Paulo, brasileira ou portuguesa (que importa?), actualmente bolseira de pós-doutoramento da FCT, e do Doutor Armando Malheiro da Silva, então arquivista em Braga e hoje professor da Universidade do Porto, na área de Ciência da Informação, embora para mim seja sempre o historiador contemporaneísta que orientei. Mas, a ideia foi prontamente aceite por todos nós: o Doutor Carlos Cordeiro (professor na Universidade dos Açores), o Mestre José Luís Lima Garcia (professor na Escola Superior de Educação da Guarda), o Doutor Luís Oliveira Andrade, da Universidade de Aveiro (que já não está fisicamente entre nós, mas cuja memória nos acompanha no nosso quotidiano), e eu próprio. Éramos seis, pelo que Seis passaria a ser uma palavra mágica, tanto aplicada 
ao número de investigadores que nos reuníamos periodicamente, na minha casa, em Figueira de Lorvão (concelho de Penacova), ou na casa Malheiro da Silva, em Paderne, no concelho de Melgaço, como ao Centro que queríamos fundar - CEIS20 (Centro de Estudos Interdisciplinares do Século XX). Interdisciplinar era, pois, uma das características essenciais da unidade de pesquisa que nessa altura vivia somente nos nossos sonhos. No entanto, também a desejámos transversal, a pesquisadores de vários países e a várias escolas do ensino superior ou do ensino básico e secundário (situação que parece hoje não estar adequada a uma noção de escola que se burocratizou, que parece mais estar interessada na forma do que na matéria, ou seja, nos métodos de ensinar, ou nem isso, do que no conteúdo científico e cultural, que é a base do conhecimento e do espírito crítico).

O resto... é a história já narrada pela minha colega Maria Manuela. A história de um centro que, para se fundar, se instalar e progredir, contou com o apoio de todos os reitores que passaram pela Universidade de Coimbra, desde 1998 ou ainda antes, Professores Rui Alarcão, Fernando Rebelo e Fernando Seabra Santos; de todos presidentes da Fundação para a Ciência e a Tecnologia, Professores Luís Magalhães, Fernando Ramôa Ribeiro e João Sentieiro; pelo ministro Professor Mariano Gago, que esteve presente na inauguração da nossa nova sede. E que teve e tem ainda a colaboração das Fundaçôes (as verdadeiras Fundações de mecenato), como a Fundação Calouste Gulbenkian e a Fundação Engenheiro António de Almeida, presidida pelo nosso colega Fernando Aguiar Branco, e da Imprensa da Universidade de Coimbra, dirigida primeiro pelo Professor Fernando Regateiro e agora pelo Professor José de Faria Costa e pela Dr. ${ }^{a}$ Maria João Padez. É a história de um centro que se organizou e reorganizou (bem ou mal), ao sabor das políticas da investigação, nem sempre consequentes, que fomos oportunamente criticando. Um Centro, sobretudo, que tem trabalhado quanto pode e como pode, editando regularmente a sua revista, Estudos do Século XX, vários ensaios nos Cadernos do Século XX, que publica três colecções, muitos livros, que organizou muitos colóquios, cujas actas têm sido editadas (a última das quais, acabada de sair pela Imprensa da Universidade, se intitula Estados Autoritários e Totalitários e suas Representaçôes), que tem organizado exposiçōes, a começar numa realizada exactamente em 1998, sobre Humberto Delgado e as eleições de 1958 para a Presidência da República, cujo cartaz (espécie de ex-libris) está na entrada da elegante «Casa das Ardenas» na rua Filipe Simões, onde viveu o linguista Prof. Paiva Boléo e o médico Dr. César Anjo, figura de grande significado da oposição ao Estado Novo de Salazar. Então, em 1998, não tínhamos ainda eira nem beira ou vivíamos em pequenos cubículos nos edifícios da Reitoria ou dos Serviços Internacionais na rua Oliveira Matos, e reuníamo-nos onde podíamos dispor de uma sala, até que a Reitoria nos destinou aquele excelente espaço.

\section{Amor à História e à Universidade}

O CEIS20 é afinal hoje a casa onde trabalhamos, onde combatemos pela história e onde sublimamos as nossas frustraçōes universitárias, «sob o signo de Bolonha», sobre as quais continuo a escrever (mesmo aposentado), pois — posso dizê-lo — para além da minha Família, que sempre constituiu o centro da minha vida, os meus grandes amores foram e são a Universidade e a História. 
Não se atrevam os colegas que aqui quiseram estar presentes, como comunicantes neste colóquio, membros e colaboradores, ou os simples amigos do CEIS20 e todos os presentes - a quem agradeço vivamente — considerar como romântica e serôdia esta verdadeira «declaração de amor». Proferiu-a o próprio Lucien Fèbvre, em relação à História, num dos textos integrados no livro cujo título - como dissemos — inspirou este encontro, Combats pour l'Histoire, colectânea publicada em 1953. Disse-o, e depois escreveu-o, na abertura a três conferências de iniciação à História, proferidas no início de 1941 e destinadas a alunos da École Normale Supérieur:

Amo a História. Se não a amasse não seria historiador. Fazer a vida em duas: consagrar uma à profissão, cumprida sem amor; reservar a outra à satisfação das necessidades profundas - algo de abominável quando a profissão que se escolheu é uma profissão de inteligência. Amo a História - e é por isso que estou feliz por vos falar, hoje, daquilo que amo. ${ }^{1}$

Quanto à Universidade, tenho-a louvado e criticado, como alguém que a ama. Perdoem a utilização exemplar dos nomes que vou proferir (porque pode parecer da minha parte uma presunção), mas criticaram-na, em várias épocas e circunstâncias, e amaram-na, Francisco Soares Franco, Almeida Garrett, Antero de Quental, António José de Almeida, Bernardino Machado, Sidónio Pais, Sobral Cid..., e tantos outros, como Joaquim de Carvalho (cujos cinquenta anos da sua morte se estão a celebrar na Figueira da Foz, sua terra natal). Rodrigues Lapa, Aurélio Quintanilha, Mário Silva ou os meus professores Sílvio Lima, Silva Dias e Miguel Baptista Pereira (só para falar daqueles que pela «lei da morte» já não estão entre nós).

\section{A Universidade, o seu sentido, em tempos de crise, e os combates pela Universidade}

Acima de tudo - e é isto que se está a esquecer, neste início de século e finais do século XX, que também já foi nosso - a Universidade é Ciência, é Cultura e é Ensino, que tanto pode viver num curso de História, de Filologia Clássica, como num curso de Física ou de Engenharia de Materiais. Não devemos esquecer que o famoso MIT (a Universidade americana é normalmente mal compreendida, sobretudo quando a ela queremos recorrer como "exemplo», na lógica do que Ortega y Gasset chamava, ironicamente, as «universidades dos países exemplares»), o MIT de que tanto se fala no domínio dos saberes práticos, tem excelentes secçōes de História, de Línguas e Literaturas e de Filosofia. Mesmo em Portugal, ainda por vezes se pensava assim. Fui professor na Universidade de Aveiro, em 1973, no então recém-criado curso de Telecomunicaçôes onde, conjuntamente com uma equipa liderada pelo Professor Silva Dias, leccionava a disciplina de... História da Cultura!

A Técnica pode e deve existir, tem de existir, e é responsável pelas grandes maravilhas do nosso tempo, mas não nos podemos deixar subjugar por ela. Por isso, no mesmo texto de que falei há pouco, Lucien Fèbvre, na altura em que analisava a sucessão do império da razão burguesa ao qual se seguia o grito de dor do proletariado, falava da

\footnotetext{
1 «Viver a História», Combates pela História I, tradução portuguesa, Lisboa, Presença, 1977, p. 37.
} 
"Tragédia do Progresso» ${ }^{2}$. E, na verdade, o domínio da técnica preocupou historiadores ou filósofos, bem como os cientistas do século XX, como Einstein. Em Portugal, Leonardo Coimbra, que teve uma formação de base no domínio das ciências exactas e naturais e da náutica, no seu texto fundamental, O problema da Educação Nacional (1926), entendia a Universidade como a alma da Educação, da Cultura e da Ciência e expressava-se desta forma, discutível sem dúvida, mesmo para o tempo em que escrevia, na qual colocava o ensino técnico num lugar à parte: «Uma Universidade é antes de mais nada, o saber teorético, seja: faculdade de ciências da natureza, faculdade de ciências do espírito e faculdade de Filosofia. O resto são as faculdades técnicas, variadas segundo as necessidades e o condicionalismo de cada região» ${ }^{3}$.

Acima de tudo, e nunca esquecendo o alarme que nos foi lançado, com algum exagero, mas com muito dramatismo e muita preocupação em relação ao futuro (preocupação saudável) por universitários, pensadores e escritores dos anos vinte e trinta do século passado, que viam, penosamente, surgir a ideia de que uma política tecnocrática devia dominar no espaço da educação, com tendência para a ligação a ideologias únicas e às práticas autoritárias ou totalitárias, deveremos hoje perguntar "O que é a Universidade?». Não defino nada - como sempre digo, as definiçôes podem levar à cristalização dos conceitos. Mas afirmo peremptoriamente - como muitos universitários o estão, felizmente, a fazer em todo o mundo, quer sejam historiadores, humanistas, filósofos, matemáticos ou engenheiros informáticos — que a Universidade e a Educação não podem estar ao serviço da técnica, de uma produtividade simples, ou simplista, numa lógica neo-liberal e pragmática, sobretudo de uma produtividade do lucro, independentemente da sua estabilidade e do seu papel social. De uma produtividade que não discute os sistemas sociais, científicos e culturais, que não se interroga e que não quer que os técnicos, os gestores, os cientistas ou os professores e os estudantes se interroguem.

Ortega y Gasset, numa famosa oração proferida em Madrid, em 1930, afirmava:

A vida é um caos, uma selva selvagem, uma confusão. O homem perde-se nela. Mas o seu espírito reage ante essa sensação de naufrágio e de perda: trabalha para encontrar na selva "vias», "caminhos»; isto é: ideias claras e firmes sobre o universo, convicções positivas sobre o que são as coisas e o mundo. O conjunto, o seu sistema, é a cultura no sentido verdadeiro da palavra; completamente ao contrário, pois, do ornamento. Cultura é o que salva do naufrágio vital, o que permite ao homem viver sem que a sua vida seja uma tragédia sem sentido ou radical envilecimento.

Não podemos viver humanamente sem ideias. [...]

$[\ldots]$

Cultura é o sistema vital das ideias em cada tempo. ${ }^{4}$

\footnotetext{
${ }^{2}$ Combates pela História, ed. port., vol. I, p. 55.

${ }^{3}$ O problema da Educação Nacional. Tese apresentado ao Congresso da Esquerda Democrática, em 26 de Abril de 1926. Porto, Marânus, 1926, p. 44.

${ }^{4}$ Misión de la Universidad, Madrid, Revista de Occidente, 1930, pp. 57-59. A tradução portuguesa é da nossa responsabilidade, mas pode ver-se outra tradução, de Filipe Nogueira, sem dúvida de melhor qualidade, na edição portuguesa recente (outra foi feita por Sant'Anna Dionísio e editada pela Seara Nova em 1946) Missão da Universidade e outros textos, Coimbra, Angelus Novus, 2003, pp. 47-48.
} 
Para Ortega, a Universidade era, acima de tudo, uma «Universidade de Cultura», embora fosse também uma escola de formação profissional e, além do mais (además), um centro de Ciência, embora se equacionasse a questão de saber se as verdadeiras unidades de investigação não deveriam viver com independência, tendo em conta que, se a Universidade deveria preparar bons profissionais cultos, não teria necessariamente de preparar cientistas. Como se vê, trata-se de um problema difícil de resolver, sobre o qual mesmo hoje se discute.

Mas também hoje se equaciona, curiosamente, o problema da falta de cultura. Tal como no tempo de Ortega y Gasset, mas agora numa época marcada pela massificação e por artificiais ideias de saber, pela lógica de conhecimentos práticos ou de «competências» (na nova gramática intelectual). Veja-se, por isso, o interesse deste texto:

Hoje atravessamos - contra certas presunções ou aparências - uma época de terrível incultura. Nunca talvez o homem médio esteve tão abaixo do seu próprio tempo, do que este tempo lhe pede. Do mesmo modo, nunca abundaram tanto as existências falsificadas, fraudulentas. Quase ninguém está no seu lugar adequado, ligado ao seu autêntico desígnio. O homem normalmente vive de subterfúgios com os quais se mente a si mesmo, fingindo ter à sua volta um mundo muito simples e arbitrário, apesar de que a consciência vital o avisa aos gritos que o seu verdadeiro mundo, o que corresponde à plena actualidade, é profundamente complexo, preciso e exigente. Mas, tem medo - o homem médio é hoje muito débil, a despeito das suas gesticulações de valentia -, tem medo de abrir-se a este mundo verdadeiro, que exigiria muito dele, e prefere falsificar a sua vida, mantendo-a hermética no casulo do seu mundo fictício e simplicíssimo. ${ }^{5}$

E, nesta mesma lógica, Ortega (que publicou primeiro o seu notável texto no jornal El Sol e por isso pedia desculpa aos «periodistas») invectiva contra os jornais que davam conta de um mundo fictício (hoje diríamos «virtual»), esquecendo o que era verdadeiramente importante: «Quanto mais importância substantiva e perdurante tem uma coisa ou pessoa menos falarão dela os jornais, e, ao invés, destacarão nas suas páginas o que esgota a sua essência em ser um «sucesso» e dar lugar a uma notícia.» ${ }^{6}$. A Universidade, ao contrário do que (segundo Ortega) sucedia, teria, pois, de intervir no mundo e numa Europa que vivia de «cabeça para baixo» («con la cabeza para abajo y los pies piruteando en lo alto»). Daí o facto de ter de se reformar e conhecer a medida da sua responsabilidade. E assim terminava o seu discurso Ortega y Gasset:

É, pois, questão de vida ou de morte para a Europa rectificar tão ridícula situação. Para isso tem a Universidade que intervir na actualidade como Universidade, tratando os grandes temas do dia a partir do seu ponto de vista próprio - cultural, profissional, científico. Deste modo não será uma instituição só para estudantes, um recinto ad usum delphinis, mas uma instituição que, envolvida na vida, nas suas urgências, nas suas paixões, há-de impor-se como um "poder espiritual» superior frente à Imprensa, representando a serenidade frente ao frenesim, a séria agudeza frente à frivolidade e à verdadeira estupidez.

\footnotetext{
${ }^{5}$ Idem, 117-118. Na edição portuguesa mais recente, p. 74.

${ }^{6}$ Idem, p. 142. Na edição portuguesa, p. 83.
} 
Então voltará a ser a Universidade o que foi nas suas melhores horas: um princípio promotor da história europeia. ${ }^{7}$

Obviamente que a vida, as urgências e as paixões do nosso tempo são outras. Perdoem-me citar, por isso, tão insistentemente este belo texto que se intitula Misión de la Universidad, de 1930, como tantos outros já o fizeram ao longo da história mais ou menos recente. Mas o certo é que actualizando o texto - falando dos jornais, mas também da rádio, e sobretudo da televisão e da Internet — não podemos deixar de pensar no sentido das palavras do filósofo espanhol, que foi tão seguido e citado, como discutido, à direita e à esquerda. Acima de tudo — tal como fiz nos ensaios "A Universidade e as "condiçōes» da imaginação" e a "A Universidade entre a Tradição e a Modernidade» ${ }^{8}$, usando outros exemplos e outros pensadores, que hoje reflectem sobre a Universidade, procurando escalpelizar os paradigmas do passado e do presente - o que desejo é apelar para a ideia de uma Universidade de conhecimento, interventiva, que ensine com competência e com exigência, utilizando as técnicas de hoje mas sem se deixar encadear por elas, pensando mais no conteúdo do que na forma, mais na independência do que na autonomia, menos na produtividade e no «sucesso» do que na formação da inteligência e do espírito crítico (não há Universidade sem Espírito Crítico), menos na lógica empresarial do que numa concepção social e comunitária que sempre fez parte da sua essência europeia.

Mas, já agora, deixem-me acrescentar alguns passos de Joaquim de Carvalho, no ano dos cinquentenário da sua morte, que, infelizmente nunca cheguei a conhecer, pois já falecera quando entrei na Universidade em 1960. O seu texto de referência foi publicado em 8 de Novembro de 1933 (faz quase neste dia 75 anos), com o título sugestivo "Reflexão outonal sobre a Universidade de todo o ano», publicado no Diário Liberal, de Lisboa. Foi um tempo de grandes discussões acerca da Universidade, como vieram a ser os decénios seguintes. Os próprios professores, na sua maioria ligados ao regime em formação, escreveram uma representação dirigida ao então ministro da Instrução Pública, queixando-se das condiçōes do ensino. Mas, intervieram também, de modo diferente, outros professores mais ou menos «marginais» em relação ao Poder, mas sempre intervenientes (Rodrigues Lapa ou Aurélio Quintanilha, Hernâni Cidade, Geraldino Brites ou Adriano Rodrigues), intelectuais como António Sérgio, «gente nova» partidária do movimento de "Renovação Democrática» (como Lobo Vilela, Joaquim Magalhães, Adeodato Barreto, Adolfo Casais Monteiro, Álvaro Ribeiro, Delfim Santos). Joaquim de Carvalho não subscreveu o texto dos seus colegas de Coimbra, mas concordou basicamente com ele no artigo citado. Permito-me ler uns passos do texto do professor de Filosofia e de História da Cultura, pois são de uma notória actualidade e entusiasmam qualquer leitor ou qualquer ouvinte. Fala sobre o tempo, sobre o sentido do estudo universitário, ou sobre a importância da cultura, numa evidente influência de Ortega y Gasset:

\footnotetext{
${ }^{7}$ Idem, pp. 142-143.

${ }^{8}$ A Universidade e as "condiçôes" da Imaginação. "Cadernos do CEIS20». Coimbra, CEIS20, 2008, e "A Universidade entre a Tradição e a Modernidade» in Revista Intellectus, ano 07, vol. I - Rio de Janeiro, 2008, http://www.intellectus.uerj.br
} 
Percorra-se com espírito equânime o plano de estudos de algumas, senão de todas as Faculdades, e a peçonhenta verdade da carência de tempo livre, para mestres e estudantes, surgirá com profunda evidência. Atirado de uma cadeira para outra cadeira, de um curso para outro curso, das aulas teóricas para as aulas práticas, o professor é inexoravelmente compelido à burocratização do magistério, ao ensino fácil e à repetição - coisas terríveis para mestres e alunos.

Para mestres, porque lhes cerram o intelecto à imaginação criadora e os convertem em provincianos do Espírito, e para os estudantes, porque lhes geram a sensação de que a aprendizagem não exige o esforço diário e a ciência é como os frutos maduros, que estão acolá à espera de quem os colha.

\section{[...]}

Escolar, estudante e estudioso são três palavras diversas, cuja diversidade não impede que toda a gente lhes reconheça o parentesco de membros de uma única família. Ser escolar é adquirir o direito de frequentar as aulas; ser estudante é, pelo menos, cumprir suficientemente os deveres da escolaridade, mas o ideal é que os escolares e os estudantes sejam estudiosos, e ser estudioso na juventude não tem a significação farisaica do jovem limitar as suas vigílias, as suas curiosidades e a sua formação interior - a qual, claro, não é o mesmo que formatura -, aos estudos oficiais da Universidade.

Todo o jovem que transita durante cinco anos por uma Faculdade e viveu à margem dos problemas eternos, dos anelos do seu tempo e não ouviu a tenuíssima voz das gerações, que nos estão dizendo ser ciência difícil e um esforço infatigável e sem descanso, frustrou a sua vida para sempre.

Pode ser um técnico útil, mas é uma alma perdida e a arrepiante verdade é que a organização vigente é uma máquina infernal de perda de almas. Costuma dizer-se que a juventude é a idade heróica, mas é, pelo menos, a única idade da vida que tem o direito absoluto ao desperdício do tempo em holocausto às nobres paixões. A ciência oficial não é toda a ciência e menos ainda toda a cultura, e o grande pecado da organização em vigor é roubar o tempo e supor que propicia ao estudante o viático intelectual para toda a vida pós-escolar.

E, noutro passo, recordando mais uma vez Ortega, escrevia Joaquim de Carvalho:

Os despojos da mortífera peçonha estão aí, bem visíveis: a crescente diminuição de vocaçôes científicas, a quebra de continuidade no ensino dos grandes mestres finados, a carência apavorante de jornais e revistas da juventude escolar, e em sua substituição sub-produtos reles de boémia pseudo-espirituosa. Podemos nós, os que nos preocupamos com a saúde moral e política da nossa Pátria, ser indiferentes ao brado de alerta contra a mortífera peçonha? Este é o facto nu e cru, e é sobre o facto, em si, descarnado e sem tintas de retórica, que deve incidir a atenção pública. Quem há aí que não sofra com magoada indignação o justificado retraimento dos nossos editores e o crescente desinteresse por tudo - tudo - que afirme qualquer faceta do Espírito?

Dir-se-ia que vivemos submergidos por uma vaga de estupidificação colectiva, mas o nosso dever elementar, espere-nos ou não o sucesso, mesmo sem esperança de êxito, é remar contra a vaga. 
Enfim - repetimos - o tempo é outro. Contudo, nunca poderemos esquecer a lição de quem nos precedeu, a que poderemos juntar os testemunhos, discutíveis, sem dúvida (não há nenhum juízo que não o seja), mas empenhados, na luta por uma Universidade e (mais latamente) um Ensino e uma Cultura ao serviço da sociedade, e não defensores de uma Universidade Empresarial ao serviço do Capital. Por exemplo, poderemos acrescentar os testemunhos do filósofo francês Jacques Derrida ${ }^{9}$ ou do canadiano, professor de literatura comparada, Bill Readings ${ }^{10}$, ou do professor de Filosofia da Educação da Universidade de Hamburgo Andrea Liesner ${ }^{11}$, ou do sociólogo da Universidade de Oxford Hermínio Martins ${ }^{12}$, ou do matemático francês Laurent Laforgue, demitido do Conseil Supérieur d'Éducation por ter denunciado que o sistema educativo francês estava em vias de destruição, ou de Christophe Charle, prestigiado historiador da Universidade de Paris I, na Introdução ao livro Les ravages de la «modernisation» universitaire en Europe $e^{13}$.

\section{Combates pela História}

Combates pela Universidade, combates pela História... Velhos e novos combates...

Também nos anos trinta ou quarenta a História passou por um momento de crise. Lucien Fèbvre nos seus Combats afirmava de forma bem clara, referindo-se ao relativismo que atingiu a Ciência:

[...] a crise da História não foi uma doença específica que atingisse unicamente a história. Foi e é um dos aspectos — o aspecto propriamente histórico de uma grande crise do espírito humano. Ou, mais precisamente, é apenas, ao mesmo tempo, um sinal e uma das consequências de uma transformação muito nítida e muito recente da atitude dos homens de Ciência, dos cientistas frente à Ciência. ${ }^{14}$

Por isso, Lucien Fèbvre e o movimento dos Annales lutavam por uma História vivida («Vivre l'Histoire» - é o título das liçōes de Lucien Fèbvre, de 1941), por uma História que não fosse uma mera narrativa do passado, mas que compreendesse a sociedade de qualquer época, sem a «actualizar», sem a tornar um artifício ideológico.

${ }^{9}$ L'Université sans condition, Paris, Éditions Galilée, 2001. Tradução portuguesa, com um Posfácio por Fernanda Bernarda, A Universidade sem condição, Coimbra, Angelus Novus, 2003. Este texto foi apresentado pela primeira vez na Universidade de Stanford (Califórnia - EUA), em Abril de 1998.

${ }^{10} \mathrm{O}$ obra, com o título original The University in ruins, publicada pela Harvard University Press, em 1996, foi completada por Diane Elam, dado que Bill Readings faleceu num desastre de aviação. Foi publicada em português: A Universidade em Ruinas, Coimbra, Angelus Novus, 2003.

11 "Education or service? Remarks on teaching and learning in the entrepreneurial university», in Educational Philosophy and Theory, vol. 38, n. ${ }^{\circ}$ 4, 2006.

12 "The marketisation of universities and some contradictions of academic knowledge-capitalism", in Metacritica. Revista de Filosofia, n. ${ }^{\circ}$ 4, 2004. Hermínio Martins escreveu depois uma versão corrigida e actualizada, em 2007.

${ }^{13}$ Christophe Charle e Charles Soulié (dir.), Les ravages de la «modernisation» universitaire en Europe, Paris, Éditions Syllepse, 2007.

${ }^{14}$ Combates pela História, ed. cit., vol. I, p. 49. 
Nós hoje, historiadores, tornamos a ter de lutar não exactamente por essa História que, apesar de muitas virtudes e de ter tido, ela própria, a sua evolução e a sua autocorrecção, esqueceu por momentos a história política, a história militar, a biografia, mesmo a história da cultura que quase reduziu à história das mentalidades. O CEIS20 foi, em parte, motivado por esse combate, com algum sucesso, mas com algumas derrotas, pois não é possível fazer frente ao espectáculo dos media, ao monopólio das editoras e das distribuições livreiras e ao seu receio de publicar obras científicas de algum volume, perante a invasão de obras pequenas e fáceis, que se lêem depressa, ou de textos volumosos para entreter, que se vão lendo ao longo dos dias.

Mas isso não sucede apenas na História. Deixámos de ter referências de autores e de «escolas» no domínio historiográfico, como deixámos de ter referências na literatura, tirando dois ou três nomes de "clássicos» (antigos, modernos ou contemporâneos) que os novos quase não conhecem e os velhos falam deles ainda para se agarrarem a «alguma coisa». Parece indiscutível que o que se vende é uma literatura esotérica, como a de Paulo Coelho, que se consome depressa e parece deixar o homem cheio de esperança e de fé, que efectivamente não tem. Ou uma literatura de mistérios históricos, que Umberto Eco lançou com grande qualidade, mas que se abastardou numa lógica de enigmas que se crêem como reais, e que são quase de pura ficção, de que o mais célebre é, evidentemente, $O$ Código Da Vinci, de Dan Brown. Ou livros grandes, cheios de história ou de "estória(s)», que custam relativamente pouco dinheiro e dão para ler (ou para não ler) durante muito tempo, como dizia a hospedeira de bordo do filme de Steven Spielberg, Terminal de Aeroporto (The Terminal), acerca de um livro sobre Napoleão, para o «apátrida» com pátria, que passou a viver num espaço de passagem para alguma coisa que constantemente se procura e se não encontra.

Temos de continuar a fazer História e de esforçar-nos para que a Memória seja não uma memória forjada pelos media, como sucedeu com o programa «Grandes Portugueses», mas que seja uma Memória captada no momento com métodos científicos e, porventura, depois orientada de forma científica e de modo pedagógico-didacticamente correcto. Devemos esforçar-nos por provar que não são os pequenos livros que por aí abundam e que são considerados verdadeiros «sucessos editoriais», de "narrativas», de «memórias», de "pequenas estórias», de algum sensacionalismo de apresentação, mesmo que sejam de algum interesse, ou outros — o que é mais grave — de aparência científica mas com intenções inconfessadas, que correspondem ao que chamamos HisTóriA. A História e toda a Ciência resulta de um parto difícil, com cesariana, e não deve ser entendida como algo que facilmente se apreende como dizia Joaquim de Carvalho. Lucien Fèbvre - mais uma vez — falando das «investigaçôes colectivas» que afinal fazem hoje parte do nosso trabalho de grupo, reafirmava sobre a História aquilo que Ortega dizia da Cultura e Joaquim de Carvalho da generalidade da Ciência e do Ensino, ou seja, que a História é uma ciência complexa como as outras, integrada em cada época e na nossa época:

A Ciência - e com isso significo a Sociedade das Ciências - a Ciência é feita por historiadores que radicam no meio da sua época: é o mesmo para os matemáticos, os físicos, os biólogos... os historiadores [...]. ${ }^{15}$

15 "Por uma história dirigida. As investigações colectivas e o futuro da História», in Combates pela História, p. 88. 
Enfim, é este o nosso «combate pela História e pela Universidade», "pela Universidade e pela História», "pela Cultura, pela Ciência e pelo Ensino».

\section{A visão realista do presente e a esperança de uma nova época. O papel do historiador}

Como vêem, este não é um combate de pessimismo, mas é um «combate». Acredito que estamos a terminar um ciclo neoliberal e consumista que nos consome o dinheiro e a alma, que consome a sociedade dos mais pobres, mas também dos mais incultos.

Ainda há poucos anos, François Furet, num livro de correspondência com Ernst Nolte sobre os temas do Fascismo e do Comunismo (que parecem ser, por vezes e infelizmente, as únicas saídas para uma crise capitalista e demoliberal, perante a falência das práticas «social-democráticas» ou de «socialismo democrático», que acabam facilmente por alinhar no sistema capitalista, vá ele por onde for, mesmo por um sistema neoliberal, repetindo velhas experiências, ainda que embelezadas por novas cosméticas, e que se sabe incapaz de resolver os problemas da economia, da sociedade e do Homem) escrevia, na abertura do opúsculo, um texto que há anos transcrevi num $\operatorname{artigo~}^{16}$, no meio do pessimismo e da esperança:

Tal é o pano de fundo melancólico deste fim de século. Aqui estamos nós confinados a um horizonte único da história, empurrados para a uniformização do mundo e para a alienação dos indivíduos à economia, condenados a retardar-lhes os efeitos sem ter qualquer domínio sobre as causas. A história apresenta-se tanto mais soberana quanto nós acabamos de perder a ilusão de a governar. Mas, como sempre, o historiador tem o dever de reagir contra aquilo que assume, na época em que escreve, um ar de fatalidade: está farto de saber que são efémeras essas espécies de evidências colectivas. As forças que trabalham pela universalização do mundo são tão poderosas que provocam encadeamentos de circunstâncias e de situaçóes incompatíveis com a ideia de lei da história. Por maioria de razão com a ideia de previsão possível. Compreender e explicar o passado deixou de ser coisa simples. ${ }^{17}$

«Eu tenho um sonho...» Quero ter um sonho ou fazer uma previsão à maneira dos filósofos da História e não de alguns «políticos» que tudo justificam, para se manterem no poder, mesmo com a aparência da mudança, como na velha afirmação (por vezes desgastada) de Giuseppe Tomasi di Lampedusa, através da personagem do Príncipe de Salinas, no livro Il Gattopardo (O Leopardo), adaptado ao cinema na

\footnotetext{
16 «O Poder da História. A História do Poder», in Actas del II Congresso Internacional História a Debate. Celebrado en Santiago de Compostela los días 14-18 julio 1999. Tomo II, Santiago de Compostela, HAD, 2000, pp. 207-211. Outra edição: in Oficinas da História, Coimbra, Edições Colibri - Faculdade de Letras da Universidade de Coimbra, 2002, pp. 177-185.

${ }^{17}$ François Furet e Ernst Nolte, Fascismo e Comunismo. Tradução portuguesa de Fascisme et Communisme (Paris, Librairie Plon, 1998). Lisboa, Gradiva, 1998, p. 9.
} 
obra-prima de Luchino Visconti: «Para que as coisas permaneçam iguais, é preciso que tudo mude.» ou, como mais vulgarmente se diz, "É preciso mudar alguma coisa para que tudo fique na mesma». Não foi isto que sucedeu presentemente com a crise do sistema bancário, no contexto do sistema neoliberal, que levou mesmo o nosso «Nobel», José Saramago ${ }^{18}$, com o notável valor de um símbolo, a pedir o julgamento do caso como "crime contra a humanidade»?

Quero acreditar que estamos no início do fim de um ciclo e espero que o futuro de novo nos traga o reaparecer dos idealismos, condicionados pelos valores de uma nova época, que inclui a ideia utópica de democracia e não aquela que por aí se desgasta no nosso dramático quotidiano. Mais do que nunca, então, os historiadores têm de "combater», com os seus estudos objectivos ("só a Ciência é revolucionária») e com os seus compromissos de cidadãos. Por isso termino com mais uma afirmação de Lucien Fèbvre, no ainda dramático mas promissor tempo de fim de guerra:

Nestes anos em que tantas angústias nos oprimem, não quero repetir com o Michelet do Peuple ${ }^{19}$ : «Jovens e velhos, estamos cansados.» Cansados, os jovens? Tenho esperança que não. Cansados, os velhos? Não quero. Para lá de tantas tragédias e perturbações, grandes claridades brilham no horizonte. No sangue e na dor cria-se uma humanidade nova. E portanto, como sempre, uma História, uma Ciência histórica à medida de tempos imprevistos prepara-se para nascer. Desejo que, antecipadamente, o meu esforço tenha sabido adivinhar e abraçar as suas direcçóes e que os meus riachos possam dilatar o seu caudal. ${ }^{20}$

\footnotetext{
18 Expresso, 18 de Outubro de 2008.

${ }^{19}$ Michelet, Le Peuple, Paris, Comptoir des Imprimeurs réunis, 1846.

${ }^{20}$ Combates pela História, Prefácio assinado de Le Souget, no Natal de 1952, ed, cit., p. 12.
} 
Série

Documentos

Imprensa da Universidade de Coimbra

Coimbra University Press

2010

- U

C • 